\title{
14 Utilisation of the archives of the Peruvian Commission for Truth and Reconciliation (CVR)
}

\author{
Ruth Elena Borja Santa Cruz
}

\section{The times of the Internal Armed Conflict (CAI)}

At the beginning of May 1980, the political group entitled the Communist Party of Peru-Shining Path (PCP-SL: Partido Comunista del Perú-Sendero Luminoso) declared war on Peru. In their actions, they burned the ballot boxes in the town of Chuschi. However, this event took place almost unnoticed, because it occurred in a remote town in the department of Ayacucho. With this, the PCP-SL, led by Abimael Guzmán Reynoso, ${ }^{1}$ began the Internal Armed Conflict (CAI: conflicto armado interno) which, over the course of around 20 years, sought the destruction of the "old state". Then, in 1984, the Túpac Amaru Revolutionary Movement (MRTA: Movimiento Revolucionario Túpac Amaru), led by Víctor Polay Campos, ${ }^{2}$ began their violent action. These movements, the PCP-SL and the MRTA, were the two groups responsible for disrupting the governability of the country, through sabotage, kidnappings, murders, assaults, planting bombs, and other action aimed at the destruction of the "old state".

The violent action by these two movements caused significant anxiety and insecurity in the population. The response of the Peruvian State was swift, manifested in repressive actions through law enforcement and brutal repression, without making any distinction between the subversive elements in these movements and the civilian population at large.

In 2000, the government of Alberto Fujimori fell, as the result of a series of allegations of corruption presented on television channels (the Vladivideos). These complaints caused a wave of protests among the population, who took to the streets as a result of the corruption and repression which had manifested itself openly in that government. Mr. Fujimori travelled abroad to Japan, and in November of the same year, from the city of Tokyo, he resigned via a fax message. The resignation was not accepted by the Congress of the Republic and Fujimori was declared morally incapable of governing the country.

Faced with such a delicate situation for governance of the country, the President of the Congress, Dr Valentín Paniagua Corazao, was appointed as provisional President. His government then created the Truth Commission 
as a high-level body of the Presidency of the Council of Ministers (PCM), by Supreme Decree No. 065-2001-PCM. This Commission was ratified and later supplemented by Dr Alejandro Toledo Manrique, on the 4th of September of the same year. Finally, the Commission was entitled the Truth and Reconciliation Commission, by Supreme Decree 101-2001-PCM.

\section{The utilisation of public and private archives for the investigation work of the CVR and the creation of its Documentation Unit}

When the CVR was commissioned to investigate the acts of violence that occurred between 1980 and 2000, this required the use of information on this period, in particular information held in the libraries and archives of public and private institutions. Within the public institutions, the documentation of the Congress of the Republic, the Judiciary, the armed forces and the police were used for this purpose. In the case of private institutions, the documentation used was sourced from non-governmental organizations (NGOs), which had taken upon themselves the defence of the victims of the CAI or internal armed conflict (Borja, 2010) during the period between 1980 and 2000.

In turn, the research carried out by the press and television was also used, in addition to the work of the Catholic and Evangelical Churches in different parts of the country. Within its organisational structure, the CVR created the Documentation Unit (DU) ${ }^{3}$ to take on the challenge of collecting and providing bibliographical and archival information to the different areas of the CVR. To meet the needs of this service to the country, contacts were established and/or agreements reached with the different state organizations and individuals who could provide both the bibliographical material and archives available to them at that time. All the material collected was managed by the DU through its archive and library. Thanks to the bibliography and documentation collected and received by the DU from public and private bodies, it was possible to obtain the vital information in the following formats:

- Dossiers of denunciations of detentions, murders and disappearances presented by the different civil and religious organizations, filed before courts and international bodies

- Reports on cases of human rights violations drafted by the Commissions of the Congress of the Republic

- Court records on complaints of human rights violations in the different geographical areas of the CAI, housed in the archives of the Judiciary and the Ombudsman's Office

- Manuals and regulations on the actions of the military and police during the internal armed conflict, submitted by the Ministry of Interior and Defence 
- Publications on cases of massacres, arrests, disappearances, murders recorded by the press and television

- Audiovisual record of television news about the CAI

- Copies of books, magazines and theses on the CAI, held in both public and private universities.

Over the passage of time, the DU received the printed and audiovisual material produced in the different areas of the CVR, as part of its work. These materials were described and subsequently, when requested, served as sources of relevant information in the investigative work of the different areas of the CVR. Subsequently, the DU drew up a proposal for a classification chart of what was to become the central archive of the CVR. The organisational structure of the institution was taken into account for this purpose, and the different areas were worked with to organise, identify and describe its series of documents. The aim of this work was to guarantee orderly handling of the documentation, which subsequently facilitated the definitive classification chart, organising and describing the documentation on the different areas of the CVR.

\section{Series produced by the CVR}

1 Testimonies: Totalling 16,917 folders, held at the five regional headquarters, nationwide, with testimonies from victims, prisoners accused of terrorism, key political figures and members of the military and police forces. This material served for the different CVR divisions to be able to identify the victims, their dramas, and the lawsuits filed against the Peruvian State.

2 Public Hearings: The CVR has dealt with a total of 21 public hearings, held in the departments where the internal armed conflict, or CAI, had the greatest presence and impact. At the hearings, the testimonies of the victims and their families were heard, narrating their stories of horror and pain to the country, before an audience. This was broadcast publicly, so that the population could fully understand and discover what had occurred in remote areas during the period of violence that Peru lived through. At the same time, theme-based hearings were held where the patterns of human rights violations were presented to specific interest groups such as women, university students, individuals who had been unlawfully detained, covering the actions of the members of the Peruvian Self-Defence Committees and the problem of forced displacement.

3 Burial sites: The National Register of Burial Sites (RNSE: Registro Nacional de Sitios de Entierro), composed of 1,055 folders on burial sites, which are held at four different regional headquarters. This register identified 4,644 burial sites that formed the basis for the work of 
exhumation, identification and delivery of the remains of the victims to their families.

4 In-depth studies: These refer to the 19 subject areas that the CVR worked on to account for the events in each of the cases, areas and subject groups in their different geographical areas. This served to provide a broad overview of the violence; identifying perpetrators, patterns of violence, intensity of violence by region, behaviour of the key players in the CAI period and the actions carried out by them. This documentation was used to prepare the recommendations presented by the CVR to both society, at large, and the Peruvian state. The cases dealt with included Uchuraccay, the universities, the indigenous peoples, Asháninka, violence and drug trafficking, Raucana, Oreja de Perro and Villa El Salvador, among others. The CVR archive was used by institutions for the dissemination of the Final Report, the strengthening of the collective memory, justice and reparations.

\section{The utilisation of the CVR archive by institutions for the dissemination of the Final Report, the strengthening of the collective memory, justice and reparations}

Circulation of the CVR Final Report. On 29 August 2003 in the city of Ayacucho, the CVR presented its Final Report in nine volumes, and on the same date Supreme Decree No. 078-2003-PCM was published, creating the transfer committees to arrange for the delivery of the CVR heritage archive to the Ombudsman's Office, as well as submitting property, information and administrative, economic and financial documentation to the Presidency of the Council of Ministers. Consequently, the transfer to the Ombudsman's Office took place in November 2003 and was formalised in December of the same year, through the signing of the transfer certificates, with their respective transfer inventories.

Total heritage archive submitted by the CVR to the Ombudsman's office

$\begin{array}{ll}\text { Testimonials } & 16,917 \text { folders } \\ \text { Photos on paper } & 13,139 \text { photos } \\ \text { Negatives } & 3,810 \text { video strips } \\ \text { Videos } & 1,109 \text { videos } \\ \text { Master's degree (BETA, HI8) } & 428 \text { exhibits } \\ \text { Audios } & 18,696 \text { cassettes } \\ 78 \text { cases investigated } & 453 \text { folders } \\ \text { Burial sites } & 1,055 \text { folders } \\ \text { Libraries } & 1,150 \text { (books, magazines) }\end{array}$

Source: CVR to DP Transfer Agreement (2003).

After the Office of the Ombudsman had received the complete records from the CVR and the recommendation for its extensive dissemination 
throughout Peruvian society, on 19 April, 2004, ${ }^{4}$ the Information Centre for the Collective Memory and Human Rights (CIMCDH: Centro de Información para la Memoria Colectiva y los Derechos Humanos) was created. This centre was responsible for the dissemination of these CVR heritage records to court authorities, universities, schools, ministries, relatives of CAI victims, academics, and any citizen who may wish to know the truth about what occurred in Peru during the period 1980-2000.

For the process of installation of the records and their functioning, several foreign cooperating bodies collaborated: the $\mathrm{EU}$, the embassies and the UN Development Programme (UNDP). During the first years of work, emphasis was placed on making the Information Centre the body responsible for disseminating the content of the CVR document archive. The work began through talks in colleges and universities. At the same time, essay and photography competitions, photographic exhibitions, conversations and fairs were also held. The dissemination work was further strengthened by attendance at national and international events, which were decisive in publicising the work carried out by the CIMCDH through its website. ${ }^{5}$

Subsequently, the testimonies of the CVR, public hearings, photographic and audiovisual archives were digitised, thereby guaranteeing the preservation of the documents and facilitating a rapid dissemination service using computerised resources. The CIMCDH began work with one director and seven staff responsible for handling enquiries and ordering and disseminating the archives created by the CVR. The staff included three archivists who, in addition to providing attention, responding to inquiries and requests, were also entrusted with preparing printed documentation for digitisation. The digitisation of testimonies required a project, the duration of which extended to two years, resulting in setting up a human rights library specialising in the CAI period.

Since the creation of the CIMCDH, both judges and prosecutors have been the professionals who have most requested the services of consultation and reproduction of court files, testimonies and audiovisual material to process the cases presented by the CVR. Copies of the requested information were delivered in full to them. Other users have been NGOs specialising in human rights, requesting information on the cases of the corresponding jurisdictions that they were following up. Such were the cases of Cayara; Rigoberto Tenorio Roca, criminal cases; Los Cabitos and other representative cases, in the constant search for justice within the context of the transgression of human rights in Peru.

In the cases of military personnel and members of the police, professionals involved in judicial proceedings have been able to request a copy of the testimonies given by victims in cases where these professionals have been entrusted with investigations, and have been duly informed that they had the opportunity to appear in the court in question and request the corresponding documentation referring to their case. Members of Parliament of the Republic have also been added to the users, in cases where they have 
requested information on specific individuals linked to national politics, where these characters have been accused of being directly involved in acts of violation of human rights during the CAI period.

When both judges and prosecutors requested information in cases of rape, these were treated with the utmost discretion and care to ensure the personal privacy of the victims. It was recommended not to make this information public, thus guaranteeing the victims' right to privacy. The information provided was carefully utilised, because it was vitally important to guarantee access to the information but, at the same time, also guarantee the privacy and personal safety of those who gave their testimonies to the CVR. When testimonies have been requested by both national and foreign university students and academics, copies of these testimonies have been given, subject to prior review to ensure that the privacy and safety of the witness was not jeopardised.

In its archives, the CIMCDH holds files considered as reserved cases. These files contain information on protected witnesses, who have requested that their names should not be made public knowledge. These case reports could only be delivered to the courts in question, while emphasising the confidentiality of the information and the responsibility that the court authority must accept in order to guarantee confidentiality.

\section{The use of the CVR heritage for reparations to victims}

One of the recommendations of the CVR was the design and execution of a Comprehensive Reparations Plan (PIR; Plan Integral de Reparaciones), for the purpose of restituting rights and compensation for human rights violations committed during the period of violence. Therefore, during the Alejandro Toledo government, under Law 28592, the Comprehensive Reparations Plan (PIR) ${ }^{6}$ was drawn up, with the aim of establishing the legal framework of the Comprehensive Reparations Plan for the victims of the CAI period. The law provides that the High Level Multisectoral Committee (CMAN), set up under Supreme Decree No. 011-2004-PCM, should be the body responsible for monitoring the state's actions and policies in the areas of peace, collective reparation and national reconciliation.

In turn, the CMAN commission is responsible for the coordination and supervision of the PIR plan. The Commission, made up of representatives of various public institutions and civic organizations, as the coordinating and supervisory body of the PIR plan has as one of its main functions to organise the work of the different state institutions for collective and symbolic reparations, on behalf of the victims of the CAI period. To undertake its functions, the CMAN requests information from the CIMCDH on the CVR archive, on communities and individuals who were victims of the period, in order to draw up these symbolic and collective reparations.

This Law also created the Unique Register of Victims (RUV: Registro Único de Victimas), to be prepared by the Reparations Council (CR; Consejo 
de Reparación) that began functioning in October 2006 as a collegiate body which joined forces with the Ministry of Justice and Human Rights at the end of 2011, and which had previously been under the Presidency of the Council of Ministers.

For the development of the work of the Reparations Council, the Information Centre provided a copy of the CVR's database of testimonies; it also provided search and copy services for the files of the former Special Prosecutors for the Ombudsman and Human Rights Office of the Public Prosecutor and the National Human Rights Coordinator that assisted in identifying, verifying and registering the victims in the Unique Register of Victims.

\section{Strengthening the memory}

Since its creation, the CVR has set out to give a voice to the forgotten; to make visible the huge gulfs of information among the Peruvian population. It also pledged to draw attention to the terrible events that occurred over the last 20 years of the 20th century. It committed to building a memorial heritage in which everyone would be included, and to rescuing the memories of those forgotten and affected by the CAI, which is so vital to the construction of Peru's democracy. The CIMCDH, upon receiving the heritage archive of the CVR, committed itself to preserving and disseminating the memory of the years 1980-2000, through the different actions undertaken during the years of its operation.

Over the years, proposals for the preservation and dissemination of the memory of the IAC period have gradually been made. One of the main proposals came from civil society, working to set up museums and memorial sites; this initiative gained the financial support of international organizations and, in a few cases, also regional and local institutions (Reátegui, 2010).

Another of the institutions that works to preserve this heritage is the CMAN. This institution organises activities aimed at populations affected by the CAI period, promoting the installation of memorial sites: memorial houses and sanctuaries. Another project of the CMAN, ${ }^{7}$ linked to the commemoration, is the organization of comic strip competitions on human rights and national reconciliation, and discussions on the importance of memorial sites for the construction of a collective memorial of these events in our country.

The Reparations Council, as part of the policy of commemoration, proposed the Unique Register of Victims (RUV) in 2014, receiving the certificate of appearing in the Peruvian Registry of UNESCO's Memory of the World, for being a heritage archive that sheds light upon the history of the victims of the CAI, becoming an important documentary heritage of our Peruvian history that can be reviewed on the CR portal.

Another institution interested in the preservation and dissemination of the memory of CAI is the Memorial Site for Tolerance and Social Inclusion 


\section{Ruth Elena Borja Santa Cruz}

(LUM) (Del Pino and Agüero, 2014) created as a centre that organises cultural and educational, research-based and commemorative events. It also encourages dialogue on human rights issues, focusing on the period of violence in Peru, which covers the period 1980-2000. The LUM was inaugurated on 17 December 2015, after a process of implementation that began in 2008 .

The German government offered a donation of $€ 2 \mathrm{~m}$ to finance the construction and maintenance of a Memorial Museum, and this financing was accepted by the Peruvian government. Through Supreme Resolution No. 059-2009-PCM, the Peruvian government created a high-level committee (CAN: Comisión de Alto Nivel) that was responsible for guiding, organising, supervising and managing the implementation of the project. During the years 2009-2011, three different committee presidents were involved: Mario Vargas Llosa, the writer; Fernando de Szyszlo, the plastic artist; and Diego García-Sayán, the jurist.

During this period, the Museum was constructed on a plot of land on the Costa Verde and an international architectural tender was put out for the design of the centre, accompanied by a debate over the appropriateness of the term Museum and a change of the name to Memorial Site.

Subsequently, work began on the museum script and the first stone for the construction of the LUM was laid, fully discussing the implementation and operation of the permanent and temporary exhibitions of the LUM and its institutional introduction to Peruvian society. In addition, the relevance of a Documentation and Research Centre was discussed. This would provide users with the different digital archives, collected from the various public and private institutions, through its virtual platform. To date, the LUM is a benchmark in memorial issues, as it organises academic essay competitions, temporary exhibitions, shows documentaries and films, as well as organising book presentations, conferences and workshops related to the subject of the recent memory of our country and other parts of the world. It holds a digital heritage collection of documents, bibliography and documentaries that has been increasing with donations and acquisitions that are the basis for studies on the CAI period. ${ }^{8}$

\section{Progress and setbacks in the implementation of the CVR recommendations}

The creation and functioning of the CVR took place in a special context; as a country, we were emerging from a period of upheaval, authoritarianism and corruption. The CVR was set up during the transitional government, led by Dr Valentín Paniagua, who gave it all the guarantees for its work; the CVR was then ratified by the elected president, Alejandro Toledo, and began its work of clarification over the events during the period 1980-2000. Since its creation, the CVR has had a number of detractors that it has had to 
deal with; among the most furious were the representatives of the political parties that were in government during the CAI period. To this were added the armed forces and police, as well as representatives of the armed groups.

This context gives us an idea of just how difficult and delicate the work undertaken actually was. In turn, the work of the CVR was accused, by some politicians, of being in favour of terrorism because, among its members, there were commissioners who were active in left-wing political parties. Representatives of the groups in arms were accused of being from the right, and traitors to the interests of the people; and by the same token, members of the armed forces were accused of wishing to destroy the honour of the military forces with lies and allegations of being violators of the human rights of the population.

After submitting its Final Report, the CVR received many questions regarding the numbers of dead and missing. Consequently, a campaign was organised whereby the media questioned the salaries of the commissioners and called into question the veracity of the events described in the Final Report. These questions sought to obstruct the implementation of the recommendations given by the CVR.

During the government of Alejandro Toledo (2001-2006), work was carried out in compliance with the recommendations of the CVR. The CMAN, the PIR, the CIMCDH and the CR were created to set up an interdisciplinary project to take into account the period of the CAI and include information on that period in schoolbooks. In addition, turning now to health, the mental health of victims was made a priority, while in education, reparations in the form of educational scholarships were set up for the children of victims. In addition, the repair and improvement of the living conditions of the people who lost their homes and whose villages were razed to the ground during the CAI period was also stipulated.

During the government of Alan García (2006-2011), there was political interference in the progress on creating the memory of the CAI period; it was claimed that there was political bias in favour of terrorism in schoolbooks, due to there being a photo of the leader, Abimael Guzman, in a cage and wearing a striped prison suit. With this, the governing party (APRA) began to control the institutions where the recommendations of the CVR were being drawn up. It was during this period that President Alan García proposed that the donation of the German government for the construction of the Memorial Museum be reallocated to the construction of hospitals, roads and schools (Ledgard, Hibbett and De La Jara, 2018). This proposal was rejected by the human rights, intellectual rights and family rights organizations of the victims.

During the government of Ollanta Humala (2011-2016), some changes were made to promote the memory of the CAI period; work continued through the CMAN, the CR, the Ministry of Education and the Ministry of Justice, but very slowly and on a low budget. The LUM opened in 2015, 
with high expectations from family members and human rights organizations; but there was rejection from the armed forces and some political representatives who considered the LUM an apology for terrorism.

\section{The current challenges for the preservation and dissemination of the CVR heritage in order to strengthen the collective memory}

The CIMCDH houses the CVR's heritage archive and is responsible for the photographic exhibition (Yuyanapaq), ${ }^{9}$ which is exhibited on the sixth floor of the National Museum; the CIMCDH has budgetary difficulties in order to be able to preserve and publicise the CVR heritage archive. The CVR does not form part of the organisational structure of the Ombudsman's Office and therefore does not have a budget assigned to it to guarantee the number of staff needed to continue the work of digitising the CVR's heritage archive. As a result, we have a reduction in personnel. Currently, the CVR functions with three people, making it difficult to circulate the heritage memory of the CAI and further strengthen it.

In addition, the Yuyanapaq photographic exhibition also suffers from a lack of the budget that is so very necessary to maintain it in good condition. Since its inauguration, it has received visits from schoolchildren and university students, and from national and foreign visitors interested in finding out about the period of the CAI.

As a donation, the LUM (Memorial Site for Tolerance and Social Inclusion) has received the photographic archive of DESCO, an institution that formerly published the magazine Que hacer (What is to be done?). This archive contains relevant information on the period of the CAI. To date, the LUM's CDI (Documentation and Research Centre) has been digitising and describing DESCO photographs to then upload them to its virtual platform and make them available to users.

Finally, we can state that the LUM is the institution that houses the largest number of archives and publications of the CAI period and has posted this on its virtual platform, with free access, becoming an important reference point to strengthen collective memory in Peru. It therefore needs to be provided with a larger budget to ensure the feasibility of continuing the work of preserving and disseminating the events of the period 1980-2000.

\section{Notes}

1 Leader of the PCP-SL political group that declared war on the country in May 1980. To date, this leader is in prison serving a life sentence.

2 Leader of the MRTA political group that has declared war on the country since 1984. This leader is currently being held in a maximum-security prison, sentenced to life imprisonment.

3 The head of the Documentation Unit of the CVR was Rosario Narvaez. 
4 Set up under Law 28592 of the 28 July of 2005, regulated by Supreme Decree No. 015-2006-JUS and its amendments with Supreme Decrees No. 003-2008-PCM and No. 047-2011-PCM.

5 Available at www.defensoria.gob.pe/el-centro-de-informacion-para-la-memoriacolectiva-y-los-dd-hh.

6 Set up under Law 28592 of 28 July 2005, regulated by Supreme Decree No. 0152006-JUS and its amendments with Supreme Decrees No. 003-2008-PCM and No. 047-2011-PCM.

7 Available at https://cman.minjus.gob.pe/reporte-de-actividades/.

8 Available at http://lum.cultura.pe/cdi/.

9 Available at http://idehpucp.pucp.edu.pe/yuyanapaq/.

\section{Bibliography}

Borja, Ruth. 2010, "Los Archivos de Derechos Humanos en Perú,” COMMA, pp. 132-133.

Degregori, Carlos Iván. 2015, “Sobre la Comisión de la Verdad y Reconciliación (CVR) en el Perú,” in: Degregori, Carlos Iván, Portugal, Tamia, Salazar, Gabriel, and Aroni, Renzo (eds.), No hay mañana sin ayer: batallas por la memoria y consolidación democrática en el Perú. Lima: IEP, pp. 27-68.

Del Pino, Ponciano, and Agüero, José Carlos. 2014, Cada uno, un lugar de memoria: Fundamentos conceptuales del Lugar de la Memoria, la Tolerancia y la Inclusión Social. Lima: LUM, pp. 21-26.

Ledgard, Denise, Hibbett, Alexandra, and de la Jara, Blas. 2018, "Retos y estrategias para una política pública de memoria: el proyecto Lugar de la Memoria, la Tolerancia y la Inclusión Social (LUM)," Cuaderno de Investigación Nº . Lima: Escuela de Gobierno y Politicas Públicas de la Pontificia Universidad Católica del Perú, pp. 15-16.

Reátegui, Félix, coord. 2010. Los sitios de la memoria: procesos sociales de la commemoración en el Perú. Lima: IDEHPUCP. Available at http://idehpucp.pucp.edu. pe/images/publicaciones/los_sitios_de_la_memoria.pdf. 